\begin{tabular}{|l|l|l|l|l|}
\hline $\begin{array}{c}\text { 118SHARE: SOCIAL WORK } \\
\text { JURNAL }\end{array}$ & VOLUME: 7 & NOMOR: 1 & HALAMAN: $1-129$ & $\begin{array}{l}\text { ISSN:2339 -0042 }(p) \\
\text { ISSN: } 2528-1577\end{array}(e)$ \\
\hline
\end{tabular}

\title{
PENGEMBANGAN EKONOMI LOKAL JATINANGOR MELALUI WISATA EDUKASI
}

\author{
Oleh: \\ Nandang Mulyana', Hani Fauziyyah ${ }^{2}$, Risna Resnawaty ${ }^{3}$ \\ 1. Pusat Studi Kewirausahaan Sosial, CSR, dan Pengembangan Masyarakat FISIP-Unpad \\ 2. Mahasiswa Program Studi Sarjana (S-1) Ilmu Kesejahteraan Sosial FISIP-Unpad \\ 3. Pusat Studi Kewirausahaan Sosial, CSR, dan Pengembangan Masyarakat FISIP-Unpad
}

\begin{abstract}
Email:
(mulyananandang@yahoo.com; fauziyahhani@gmail.com; risna.resnawaty@unpad.ac.id )
\end{abstract}

\begin{abstract}
Abstrak
Jatinangor merupakan kawasan industri yang banyak terdapat perguruan tinggi. Jatinangor menjadi wilayah yang paling banyak didatangi oleh orang dari luar daerah baik itu untuk melanjutkan pendidikannya maupun untuk usaha. Hal ini dikarenakan di Jatinangor terdapat perguruan tinggi dengan jumlah mahasiswa yang besar. Kehadiran pendatang setiap tahun ini menjadi sebuah potensi untuk dimanfaatkan dari pengembangan masyarakat Jatinangor itu sendiri.

Salah satu program yang memanfaatkan potensi yang dimiliki oleh Jatinangor adalah wisata edukasi. Program ini berkaitan dengan tingginya masyarakat untuk melanjutkan pendidikan di perguruan tinggi yang ada di Jatinangor. Wisata edukasi di Jatinangor tersebut juga diarahkan dengan melibatkan masyarakat sekitar kampus yang ada di Jatinangor. Selain itu, wisata edukasi ini juga sebagai salah satu bentuk pengamalan dari tri darma perguruan tinggi yaitu pengebdian kepada masyarakat.

Keberhasilan pengembangan ekonomi masyarakt melalui wisata edukasi ini tentunya tidak terlepas dari keterlibatan semua pihak. Pihak perguruan tinggi yang mempunyai sarana dan informasi yang dapat disebarkan kepada masyarakat. Di sisi lain masyarakat juga akan terdongkrak ekonominya dengan terlibat dalam wisata edukasi. Sementara wisatawan akan terbantu dengan informasi yang diterimanya.

Kata kunsi : wisata edukasi, pengembangan ekonomi lokal, pengembangan masyarakat.
\end{abstract}

\section{Pendahuluan}

Jatinangor adalah salah satu kecamatan yang berada di Kabupaten Sumedang. Lokasinya tidak jauh dari Ibukota Provinsi Jawa Barat, Bandung. Akses menuju Jatinangor terbilang mudah karena dilewati oleh TOL Cipularang yang merupakan jalan tol yang paling padat karena menghubungkan dua kota besar di Indonesia yakni JakartaBandung. Secara lokasi Jatinangor juga, menjadi jalur strategis penghubung kota-kota di Jawa Barat seperti Bandung, Sumedang, Garut, Tasikmalaya, dan Majalengka.

Kecamatan Jatinangor memiliki aset lokal yang luar biasa, hampir berbagai aspek dimiliki oleh kecamatan ini. Bidang pendidikan, sejarah dan kesenian daerah berada di Jatinangor. Bidang pendidikan, Jatinangor memiliki 4 Perguruan tinggi diantaranya Institut Teknologi Bandung, Universitas Padjadjaran, Sekolah Tinggi Pemerintahan Dalam Negeri dan Institut Koperasi Indonesia. Keempat kampus tersebut, mempunyai jumlah mahasiswa yang tidak sedikit jumlahnya. Direktur Marketing Skyland City Cantya Van Hopper mengatakan bahwa jumlah mahasiswa di Jatinangor ada sekitar 50.000 jiwa.

Keistimewaan itu, ditambah dengan masuknya dua perguruan tinggi dari 4 
perguruan tinggi yang ada di Jatinangor kedalam 25 Kampus terbaik versi BAN-PT karena berakreditasi A. Kampus tersebut adalah Universitas Padjadjaran dan Institut Teknologi Bandung. Kedua perguruan tinggi tersebut menjadi nilai daya tarik kecamatan Jatinangor di mata masyarakat luas. Tidak sedikit SMA dan Lembaga-lembaga untuk berkunjung ke Kecamatan Jatinangor dengan rangka studytour atau studi banding.

Usaha wisata edukasi bertujuan untuk mengenalkan aset kelokalan khususnya bidang pendidikan menjadi icon daerah serta memotivasi siswa/i SMA untuk menempuh pendidikan di perguruan tinggi. Aset lokal bukan hanya terkait sumber daya alam saja melainkan sumber-sumber ekonomi daerah setempat yang dapat dimanfaatkan sebagai usaha di kemudian hari, ia dapat berupa Sumber Daya Alam ataupun Sumber Daya Manusia.

Kecamatan Jatinangor sudah dikelilingi oleh investor dari luar daerah. Tidak hanya itu, tidak sedikit pekerja yang berada di Jatinangor merupakan warga diluar Jatinangor. Padahal, memiliki sumberdaya manusia yang tidak sedikit namun sayangnya, warga asli setempat seakan tersingkirkan oleh pendatang dari luar daerah. Hal ini akan menyebabkan munculnya permasalahan pengangguran. Dengan demikian perlu program pemberdayaan bagi pengangguran yang ada di Kecamatan Jatinangor. Dengan program wisata edukiasi ini pengangguran yang ada di Jatinangor akan diberdayakan untuk menjadi guide atau lainnya dalam mengeksplorasi daerah tempat tinggalnya sendiri.

\section{Tinjauan Pustaka}

\section{Pengembangan Ekonomi Lokal}

Pengembangan ekonomi lokal menurut Blakely dan Bradshaw adalah proses dimana pemerintah lokal dan organisasi masyarakat terlibat untuk mendorong, merangsang, memelihara, aktivitas usaha untuk menciptakan lapangan pekerjaan. Pengembangan ekonomi lokal adalah suatu proses yang melibatkan pembentukan kelembagaan baru, perkembangan industri baru, pengembangan kapasitas pekerja untuk menghasilkan produk yang lebih bermutu, identifikasi pasar baru serta pendirian usahausaha baru. Sedangkan menurut Wold Bank (2001) adalah proses dimana para pelaku pembangunan, bekerja kolektif dengan mitra dari sektor publik, swasta dan non pemerintah, untuk menciptakan kondisi lebih baik bagi pertumbuhan ekonomi dan kesempatan kerja (dalam Nurzaman, 2002).

Peranan pemerintah daerah dalam pengembangan ekonomi lokal sangat penting, dalam hal ini pemerintah daerah berperan menjalankan fungsinya sebagai pelopor pengembangan, koordinator, fasilitator, dan stimulator. Peranan pemerintah daerah juga sangat diperlukan dalam hal memperhatikan infrastruktur yang digunakan dalam kegiatan bisnis dan industri, serta peningkatan kualitas kehidupan masyarakat. Selain pemerintah daerah, peranan swasta dan kelompok masyarakat juga diperlukan dalam kegiatan manajemen wilayah dan pencarian 16 solusi atas permasalahan tertentu. Sementara itu, salah satu kebijaksanaan pembangunan ekonomi lokal didasarkan pada prinsip keuntungan kompetitif, salah satunya melalui pengembangan potensi ekonomi daerah (Sjafrizal, 2008). Potensi ekonomi daerah didefinisikan oleh Suparmoko (2002) sebagai "kemampuan ekonomi yang ada di daerah yang mungkin dan layak dikembangkan sehingga akan terus berkembang menjadi sumber penghidupan rakyat setempat bahkan dapat mendorong perekonomian daerah secara keseluruhan untuk berkembang dengan sendirinya dan berkesinambungan." Sumihardjo (2008) menjelaskan bahwa pengembangan sektor unggulan yang dimiliki daerah tercermin pada visi dan misi daerah yang tertuang di dalam rencana pembangunan jangka panjang daerah (RPJPD) dan rencana jangka menengah daerah (RPJMD). Hal tersebut merupakan upaya pemerintah dalam pengembangan potensi daerah yang tertuang dalam perencanaan pembangunan daerah.

Penyelenggaraan pemerintahan di bidang pembangunan pada dasarnya adalah kunci keberhasilan pengembangan potensi ekonomi lokal untuk menguatkan daya saing daerah. Muktianto (2005) menjelaskan bahwa 
pendekatan yang umum dalam pengembangan potensi daerah dengan cara menelaah komponen Produk Domestik Regional Bruto (PDRB), komponen sumber daya manusia, teknologi dan sistem kelembagaan. (dikutip dari Sumiharjo, 2008, Jurnal Administrasi Publik (JAP), Vol 1, No.1 | 191 h.12). Dalam menelaah PDRB dilakukan untuk mengetahui potensi basis dan non basis. Suatu daerah yang memiliki keunggulan memberikan kekhasan tersendiri yang tidak ada pada daerah lain, sehingga sektor 17 unggulan tadi dapat dikatakan sebagai kegiatan basis (Triyuwono \& Yustika, 2003).

Tarigan (2002) menjelaskan bahwa teori basis ekonomi mendasarkan pandangannya bahwa laju pertumbuhan ekonomi suatu wilayah ditentukan oleh besarnya peningkatan ekspor dari wilayah tersebut. Perekonomian regional dapat dibagi menjadi dua sektor, yaitu kegiatan basis dan bukan basis. Kegiatan basis adalah mengekspor barang dan jasa ke tempat-tempat di luar batas-batas perekonomian masyarakat yang bersangkutan. Sedangkan kegiatan bukan basis adalah kegiatan yang tidak mengekspor, yakni hanya kegiatan yang dilakukan untuk memenuhi kebutuhan di dalam daerah itu sendiri.

Bertambah banyaknya kegiatan basis di dalam suatu daerah akan menambah permintaan terhadap barang dan jasa di dalamnya dan menimbulkan kenaikan volume kegiatan bukan basis. Sebaliknya, berkurangnya kegiatan basis akan mengakibatkan berkurangnya pendapatan yang mengalir masuk ke dalam daerah yang bersangkutan dan turunnya permintaan terhadap produk dari kegiatan bukan basis. Dengan demikian kegiatan basis ekonomi mempunyai peranan sebagai penggerak pertama (primer mover rule), sedangkan setiap perubahan mempunyai "efek multiplier" terhadap perekonomian regional, baik dalam jangka pendek maupun jangka panjang. Untuk mengetahui sektor basis dan bukan basis antara lain menggunakan metode analisis "location quantient" (LQ). (Triyuwono \& Yustika, 2003).
Dengan mengetahui kegiatan basis disuatu daerah berdasarkan potensi yang dimilikinya, maka dapat menguatkan daya saing daerah tersebut. Menurut 18 Abdullah (2002) "daya saing daerah adalah kemampuan perekonomian daerah dalam mencapai pertumbuhan tingkat kesejahteraan yang tinggi dan berkelanjutan dengan tetap terbuka pada persaingan domestik dan internasional." Indikatorindikator utama dan prinsip-prinsip penentu daya saing daerah salah satunya adalah perekonomian daerah. Prinsip-prinsip kinerja perekonomian daerah yang mempengaruhi daya saing daerah yakni:

- Nilai tambah merefleksikan produktivitas perekonomian setidaknya jangka pendek.

- Akumulasi modal mutlak diperlukan untuk meningkatkan daya saing dalam jangka panjang.

- Kemakmuran suatu daerah mencerminkan kinerja ekonomi dimasa lalu.

- Kompetisi yang didorong mekanisme pasar akan meningkatkan kinerja ekonomi suatu daerah. Semakin ketat kompetisi pada suatu perekonomian daerah, maka akan semakin kompetitif perusahaan-perusahaan yang akan bersaing secara internasional maupun domestik (dalam Hermayanti (2013).

\section{Community Development}

Community (Bambang, 2007) dalam arti komunitas bermakna sebagai:

1. Kelompok sosial yang bertempat tinggal di lokasi tertentu, memiliki kebudayaan dan sejarah yang sama.

2. Kesatuan pemukiman yang di atasnya terdapat kota kecil/town, kota atau kota besar/city.

Menurut Bambang (2007) Community development pada garis besarnya dapat ditinjau dalam dua pengertian yaitu sebagai berikut:

- Dalam arti luas bermakna sebagai perubahan sosial berencana dengan sasaran perbaikan dan peningkatan bidang ekonomi dan sosial. 
- Dalam arti sempit adalah perubahan sosial berencana di lokasi tertentu: dusun, kampung, desa, kota kecil dan kota besar, dikaitkan dengan proyek yang berhubungan dengan upaya pemenuhan dari kebutuhan lokal, sepanjang mampu di kelola sendiri dan dengan bantuan sementara dari pihak luar.

Esensi community development yang kemudian mengilhami model pembangunan yang berpusat pada rakyat, adalah upaya pemberdayaan (empowerment) terhadap rakyat berdasarkan integrasi ide-ide kemandirian. Masyarakat adalah pelaku yang menentukan tujuan, mengontrol sumberdaya dan mengarahkan proses pendayagunaan sumberdaya. Titik tekannya terletak pada kewenangan komunitas mengelola sumberdaya dalam mewujudkan kepentingannya. Kegiatan ini dirancang berdasarkan prakarsa dan partisipasi masyarakat dengan orientasi kebutuhan, potensi dan kemampuan komunitas lokal, namun memperhatikan variasi dan perbedaan yang ada dalam komunitas.

Menurut Tjokrowinoto (dalam Bambang, 2007), titik berat dari community development terletak pada pembangunan masyarakatnya, dengan titik tekan pada pembentukan kader pembangunan yang diharapkan dapat menopang tercapainya masyarakat yang berswasembada. Asasnya adalah pembangunan integral, kekuatan sendiri dan pemufakatan bersama.

- Asas pembangunan integral adalah pembangunan yang seimbang dari semua segi masyarakat sehingga menjamin perkembangan yang selaras dan tidak berat sebelah, tetapi perlu diingat bahwa untuk masa permulaan titik beratnya terutama harus diletakkan dalam pembangunan ekonomi.

- Asas kekuatan sendiri bahwa tiap usaha pertama-tama harus didasarkan kepada kekuatan atau kemampuan sendiri dan tidak hanya menunggu pemberian dari pemerintah.
- Asas pemufakatan bersama diartikan bahwa pembangunan harus dilaksanakan di lapangan yang benarbenar dirasakan sebagai kebutuhan oleh masyarakat yang bersangkutan, sedangkan keputusan melaksanakan suatu proyek bukan berdasarkan atas perintah atasan, melainkan merupakan putusan bersama dari anggota-anggota masyarakat.

Menurut Dunheim (dalam Bambang, 2007), Community Development berarti usaha terorganisir untuk memperbaiki kondisi kehidupan komunitas dan peningkatan kemampuan berintegrasi dan berkembang secara mandiri, dengan unsurnya: program berencana, pembangkitan tekad, tidak tergantung pada bantuan pihak luar.

Menurut Nelson dan Ramsay (dalam Bambang, 2007) berpendapat bahwa Community Development adalah proses pendidikan untuk bertindak, masyarakat disiapkan untuk mewujudkan tujuan komunitas secara demokratis. Pemimpin berperan sebagai agen untuk membentuk pengalaman belajar bagi komunitas dari pada sebagai penggerak tercapainya sasaran program.

Menurut Maskun (dalam Bambang, 2007): Community Development adalah program yang berusaha menjangkau masyarakat yang kondisi sosial ekonominya masih dalam keadaan relatif rendah dan sulit untuk berkehidupan memenuhi syarat kelayakan dan kesejahteraan.

Community Development oleh Dunham 1970 (dalam Chisinau, 2005) didefinisikan sebagai "the conscientious process of social interaction and that peculiar technique (...) which have at least one of the following objectives:

- $\quad$ Solving the basic needs and obtaining and maintaining a balance between the needs and resources of a community.

- Helping people treat more efficiently their problems and their aims, by assisting them in developing, strengthening and maintaining their participation, self-control and cooperation skills. 
- Producing change within community and group relations, and within community decision making center.

Dalam pengertian fasilitator, Community Development diartikan suatu proses, yang terkadang memerlukan bantuan dari fasilitator, dimana sekelompok masyarakat mengidentifikasikan permasalahan yang sedang mereka hadapi dan terlibat dalam penyelesaian masalah tersebut dengan memanfaatkan sumberdaya yang mereka miliki tetapi kadang-kadang harus menggunakan sumberdaya dari tempat lain. Community Development melibatkan setiap individu di dalam kelompok untuk menghadapi permasalahan bersama. Community Development bertujuan membentuk kelompok masyarakat yang kuat, sehingga dapat mengatasi setiap permasalahan yang dihadapi kelompok tersebut.

Pemberdayaan

dimaksudkan untuk meningkatkan kemampuan dan kemandirian masyarakat dalam meningkatkan taraf hidupnya. Pemberdayaan sendiri merupakan suatu proses yang berjalan terus menerus.

Istilah pemberdayaan (empowerment) muncul hampir bersamaan dengan adanya kesadaran pada perlunya partisipasi masyarakat dalam pembangunan. Diasumsikan bahwa kegiatan pembangunan itu seharusnya mampu merangsang proses kemandirian masyarakat (self sustaining process). Tanpa partisipasi masyarakat, proses kemandirian tersebut tidak akan memperoleh kemajuan.

Pada tataran konseptual istilah pemberdayaan dapat dikaitkan dengan proses transformasi sosial, ekonomi, dan bahkan politik (kekuasaan). Secara definisi, pemberdayaan merupakan proses penumbuhan kekuasaan atau kemampuan diri. Melalui proses pemberdayaan maka diasumsikan seseorang dari strata sosial terendah sekalipun bisa terangkat dan muncul menjadi bagian dari lapisan masyarakat menengah atas. Akan tetapi, pada prakteknya proses pemberdayaan membutuhkan bantuan orang lain. Tanpa bantuan tersebut tidak mungkin proses akan dapat berjalan dengan baik dan sesuai harapan.
Untuk itu harus ada seseorang atau institusi yang bertindah sebagai pemicu kemajuan (enabler). Dan "orang kuat" yang sering menjadi andalan tidak lain adalah pemerintah.

Para ahli menetapkan bermacammacam model dalam pelaksanaan Community Development. Model yang paling sering dipakai (Chisinau, 2005) yaitu:

- Organization of the Neighbourhood Dalam model ini Community Development dimanfaatkan untuk membentuk solidaritas di antara masyarakat yang berdekatan/bertetangga. Setiap anggota kelompok berlaku sebagai individu yang bekerjasama menghadapi sebuah permasalahan bersama.

- Community Planning Dalam model ini Community Development dimanfaatkan untuk mengkoordinasikan anggota suatu kelompok masyarakat yang lebih luas untuk mengatasi permasalahan yang lebih kompleks.

- Program Development Dalam model ini anggota kelompok terlibat dalam setiap tahap pembangunan mulai dari perencanaan hingga pelaksanaan kegiatan. Para anggota berpikir, menganalisa, merencanakan, mengatur dan mengevaluasi kegiatan pembangunan dengan kemampuan yang mereka miliki. Model ini sering disebut juga dengan prinsip partisipatif.

\section{Metode}

Kajian ini menggunakan data sekunder yang didasarkan kepada studi dokumentasi dan pustaka. Studi dokumentasi lebih diarahkan untuk mengkaji dan menganalisis hasil laporan serta data yang telah dipublikasikan yang berkaitan dengan fenomena yang dikaji. Sementara itu studi pustaka lebih diarahkan untuk menganlisis fenomena yang ada didasarkan kepada konsep atau teori yang sesuai dengan fenomena yang dikaji 


\section{Pengembangan Ekonomi Lokal melalui Wisata Edukasi}

Keberadaan perguruan tinggi di Kecamatan Jatinangor menjadi aset yang berharga. Hal ini dikarenakan perguruan tinggi yang ada di Jatinangor akan menjadi buruan dari siswa SMA untuk melanjutkan pendidikannya. Selain itu banyak juga lembaga pendidikan khususnya SMA yang mengunjungi Jatinangor untuk mengadakan study tour di perguruan tinggi yang ada di Jatinangor. Untuk membantu para pendatang yang ingin melanjutkan pendidikan di Jatinangor maka diperlukan adanya program tertentu. Salah satunya dengan program education tour.

Jatinangor Education Tour adalah wisata pendidikan perguruan tinggi (ITB, Unpad, IKOPIN dan IPDN) dengan kegiatannya ialah tur kampus dan pemberian informasi-informasi terkait kampus yang dikunjungi. Pangsa pasar yang dituju yaitu wisatawan luar daerah khususnya sekolahsekolah yang ingin mengadakan studytour khususnya siswa/i kelas 3 SMA.

Lokasi dari usaha Jatinangor Education Tour adalah kampus-kampus yang ada di Jatinangor diantaranya, Universitas Padjadjaran, Institut Teknologi Bandung, Institut Koperasi Indonesia dan Institut Pemerintahan Dalam Negeri.

Secara heksagonal pengembangan ekonomi lokal dalam program Jatinangor Education Tour ini dapat ditinjau dengan;

\section{a. Kelompok Sasaran}

Dalam proses menjalankan usaha perlu adanya modal. Jatinangor Education Tour dapat menggaet pelaku usaha lokal maupun bukan berasal dari daerah setempat. Pengelola usaha ditargetkan akan dijalankan oleh warga lokal selaku tuan rumah serta mahasiswa/i kampus setempat.

Investor luar memiliki potensi yang lebih ketimbang dari lokal. Usaha-usaha yang ada di Jatinangor merupakan para pengusaha yang berasal dari luar daerah.

\section{b. Faktor Lokasi}

Jatinangor Education Tour berlokasi di Kecamatan Jatinangor, Kab. Sumedang yang merupakan lokasi dari 4 kampus diantaranya Universitas Padjadjaran, Institut Teknologi Bandung, Institut Manajemen Koperasi Indonesia dan Institut Pemerintahan Dalam Negeri. Jika dirincikan bahwa 2 merupakan Perguruan Tinggi Negeri, 1 merupakan Lembaga Pendidikan Tinggi Kedinasan dan 1 lagi merupakan Lembaga Perguruan Tinggi Swasta.

Jarak lokasi dari satu kampus dengan kampus lainnya tidaklah begitu jauh, masih dalam satu kecamatan dan di jalan yang sama. Jatinangor merupakan kecamatan yang tidak jauh dari pusat Kota Bandung secara sarana transportasi mudah dan keadaan infrastrukturnya masih tergolong baik. Sehingga memungkinkan adanya peluang kerjasama dari luar dalam rangka pengembangan usaha ini.

Dampak dari adanya 4 kampus tersebut salahsatunya yaitu pemukiman menjadi padat sehingga pembangunan di Kawasan Jatinangor menjadi cepat dan padat. Selain itu, tenaga kerja memerlukan pelatihan-pelatihan keterampilan kerja agar dapat menciptakan tenaga kerja yang professional.

\section{c. Keterkaitan dan Fokus Kebijakan}

Pelaksanaan usaha JET akan merekrut tenaga kerja dari masyarakat setempat dengan tujuan untuk mengurangi angka pengangguran di Jatinangor serta melakukan pemberdayaan masyarakat.

\section{d. Pembangunan Berkelanjutan}

Pengembangan usaha didapat dilakukan dengan pengembangan inovasi program tour-nya dan pemberdayaan masyarakat dalam upaya peningkatan kesejahteraan khususnya pemuda-pemuda setempat yang merupakan focus untuk dijadikan rektrut tenaga kerja usaha.

\section{e. Tata Kepemerintahaan}

Dalam menjalankan usaha ini, perlu adanya kemitraan dengan pihak kampus. Kampus-kampus di Jatinangor sebagai tempat usaha dilaksanakan sehingga perlu adanya komunikasi yang baik antara pihak kampus dengan pengusaha JET untuk membahas lebih dalam terkait usaha.

\section{f. Proses Manajamen}


Stakeholder yang berperan dalam usaha JET (Jatinangor Education Tour):

1. Kabupaten/Kecamatan setempat, berperan untuk membantu dalam proses pendataan Sumber Daya Manusia untuk perekrutan tenaga kerja dan sebagai penghubung ke sistem sumber yang lainnya.

2. Kampus (UNPAD, IPDN, IKOPIN dan ITB), berperan sebagai partner bisnis usaha JET.

3. Dinas Pendidikan Daerah, berperan dalam perumusan konsep usaha agar sesuai dalam konsep pendidikan yang ada dan membantu meningkatkan promosi ke lembaga pendidikan.

4. BEM Kema Universitas di setiap Kampus-kampus, berperan untuk kerjasama dalam perekrutan tenaga kerja untuk pendampingan perjalanan wisata kampus.

5. Dinas Perdagangan dan Perindustrian, berperan dalam pemberian fasilitas untuk pelatihan wirausaha dan manajemen sumberdaya.

6. Dinas Pariwisata dan Kebudayaan, berperan dalam pelatihan pengelolaan perjalanan dan pendampingan wisata dan bermitra untuk menjadikan JET sebagai icon Jatinangor.

Selain itu, peran praktik Pekerja Sosial juga sangat penting. Peran tersebut diantaranya;

\section{Fasilitator}

Dalam literatur pekerjaan sosial, peranan "fasilitator" sering disebut sebagai "pemungkin" (enabler). Keduanya bahkan sering dipertukarkan satu-sama lain. Peran sebagai pemungkin atau fasilitator bertujuan untuk membantu klien agar menjadi mampu menangani tekanan situasional atau transisional.

Dalam penyelenggaraan Jatinangor education tour, peran fasilitator adalah memfasilitasi warga setempat untuk mengoptimalkan potensi-potensi yang dimilikinya dengan tujuan mengembangkan ekonomi kelokalan sebagai ciri khas dari daerah
Jatinangor. Hal tersebut terbagi kedalam beberapa point:

- Peran fasilitator untuk melakukan penyadaran. Pekerja sosial melakukan penyadaran kepada masyarakat Jatinangor bahwa masyarakat setempat memiliki potensi yang sangat bagus untuk dikembangkan salahsatunya adanya 4 kampus besar di Kecamatan Jatinangor yang bisa dimaksimalkan sebagai lapangan kerja warga setempat dan untuk menjalankannya, peran fasilitator berperan untuk membangun relasi dikhususkan antara lembaga kelokalan dengan pihak kampus.

- Peran fasilitator untuk pelembagaan/pengorganisasian.

Mengembangkan kapasitas kelembagaan masyarakat, pemerintahan dan pihak kampus serta mengoptimalkan pemanfaatan sumber daya

- Peran fasilitator untuk pengembangan

kemandirian/otonomi/kedaulatan. Mengembangkan inovasi dalam masyarakat berdasarkan aspirasi dari masyarakat.

2. Broker

Peran pekerja sosial sebagai broker tidak jauh berbeda dengan peran broker di pasar modal. Seperti halnya di pasar modal, dalam PM terdapat klien atau konsumen. Namun demikian, pekerja sosial melakukan transaksi dalam pasar lain, yakni jaringan pelayanan sosial. Pemahaman pekerja sosial yang menjadi broker mengenai kualitas pelayanan sosial di sekitar lingkungannya merupakan aspek penting dalam memenuhi keinginan kliennya memperoleh "keuntungan" maksimal.

Jatinangor Education Tour merupakan gagasan yang mengoptimalkan potensi dari Kecamatan Jatinangor. Peran pada pekerja sosial seperti pelaksanaan usaha tersebut-pun diserahkan pada 


\begin{tabular}{|c|c|c|c|c|}
\hline $\begin{array}{c}\text { 118SHARE: SOCIAL WORK } \\
\text { JURNAL }\end{array}$ & VOLUME: 7 & NOMOR: 1 & HALAMAN: $1-129$ & $\begin{array}{l}\text { ISSN:2339 -0042 (p) } \\
\text { ISSN: 2528-1577 }(e)\end{array}$ \\
\hline
\end{tabular}

sumberdaya manusia setempat agar masyarakat setempat mendapatkan keuntungan dari adanya usaha JET.

3. Mediator

Pekerja sosial sering melakukan peran mediator dalam berbagai kegiatan pertolongannya. Peran mediator diperlukan terutama pada saat terdapat perbedaan yang mencolok dan mengarah pada konflik antara berbagai pihak. Pekerja sosial berperan sebagai "fungsi kekuatan ketiga" untuk menjembatani antara anggota kelompok dan sistem lingkungan yang menghambatnya.

Dari pelaksanaan usaha JET, pekerjasosial berperan untuk menjembatani pemerintah, masyarakat Jatinangor dan pihak kampus dengan maksud agar tidak ada pihak yang lebih mendominasi dan terdeskritifkan jalannya usaha JET.

4. Pengetahuan dan Keterampilan

Agar sumberdaya manusia yang ada bekerja secara professional perlu adanya pekerja sosial yang berperan untuk meningkatkan pengetahuan serta keterampilan dari pelaksana usaha JET.

Dari keempat peran diatas merupakan peran dari Praktik Pekerja Sosial dalam pelaksanaan Pengembangan Ekonomi Lokal dengan tujuan memajukan Jatinangor dengan asset kelokalan.

\section{Penutup}

Jatinangor education tour merupakan bussines plan yang berdasarkan asset kelokalan di Jatinangor. Dalam pelaksanaannya, diperlukan kerjasama dengan segala pihak dari mulai pemerintahan setempat, dinas terkait, masyarakat Jatinangor, Mahasiswa/i ke empat perguruan tinggi yang ada di Jatinangor, investor dan Pekerja Sosial. Elemen tersebut mempunyai peran yang sama pentingnya dalam menjalankan usaha JET.

\section{DAFTAR PUSTAKA}

Blakely \& Bradshaw. 2002. Planning Local Econo-mic Development, Theory and Practice. Califor-

Dendi, A. H. R. \& Mahman, R. 2007. Forum Pengembangan Ekonomi Lokalkonsep, Strategi dan Metode; Perspektif dan Pengalaman Nusa Tenggara. GTZ-GLG dan Departemen Dalam Negeri Indonesia.

Indratno, I. \& Agustina. I. H. 2005. Studi Kemam-puan Masyarakat Dalam Pengembangan Eko-nomi Lokal Sebagai Upaya Pengentasan Kemiskinan. MIMBAR, Jurnal Sosial dan Pembangunan, 21(3): 416-429.

Martati, Indah.Suminto danSyarifuddin, Andi. 2013. Model Penciptaan Lapangan Kerja Melalui Pengembangan Ekonomi Lokal Pada Kecamatan Samarinda Ilir. Samarinda: Manajemen Pemasaran, Politeknik Negeri Samarinda. JMK, VOL. 15, NO. 2, September 2013, 123-130 ISSN 1411-1438

Neni. 2013. http://mahaneni.blogspot.co.id/2013/ 09/peran-pekerja-sosial-dalampengembangan.html dikutip pada 21 November 2016 pukul 23.48 wib.

Raharjo, ST. 2015. "Pekerjaan Sosial Generalis, Suatu Pengantar Bekerja Bersama Organisasi dan Komunitas", Edisi Revisi Buku, Unpad Press,

Raharjo, ST. 2015. "Dasar Pengetahuan Pekerjaan Sosial”, Buku, Unpad Press

Raharjo, ST., Taftazani, BM., Apsari, NC., Santoso, MB. 2016. "PANDUAN PRAKTIKUM MIKRO (Konseling dan Pengembangan Diri)". Buku . Unpad Press.

Raharjo, ST. 2015. "Assessment dan Wawancara dalam Prakti Pekerjaan 


\begin{tabular}{|c|c|c|c|c|}
\hline $\begin{array}{c}\text { 118SHARE: SOCIAL WORK } \\
\text { JURNAL }\end{array}$ & VOLUME: 7 & NOMOR: 1 & HALAMAN: $1-129$ & $\begin{array}{l}\text { ISSN:2339 -0042 }(p) \\
\text { ISSN: } 2528-1577 \\
(e)\end{array}$ \\
\hline
\end{tabular}

Sosial dan Kesejahteraan Sosial", Edisi Revisi Buku, Unpad Press

Suharto,

Edi.

2010.

www.policy.hu/suharto/modul-

a/makindo_34.htm dikutip pada

Selasa, 22 November 2016 pukul 00.33 wib.

http://www.tribunnews.com/regional/2014/12

/16/pengembang-kian-getol-bikin-

apartemen-mahasiswa

http://www.bandungkab.go.id/arsip/2093/info rmasi-publik-dinas-koperasi,-ukm,perindustrian-danperdagangan\#sthash.J2njLtqQ.dpuf diakses pada 20 Desember 2016 pukul 22.01 wib nia: Sage Publication.

http://digilib.unila.ac.id/11624/17/BAB\%20II. pdf

United Nations Human Settlements Programme. 2005. The Local Economic Development Series, Promoting Local Development through Strategic Planning Volume 3: Toolkit. Nairobi: United Nations Human Settlements Programme (UNHABITAT). 